Discourse and Communication for Sustainable Education, vol. 7, no. 2, pp. 52-67, 2016

\title{
Culture in Sustainability - Defining Cultural Sustainability in Education
}

\author{
Marja Laine \\ University of Helsinki, Finland
}

\begin{abstract}
The definition of cultural sustainability in education is explored in this article by looking into conceptions of cultural sustainability collected through expert queries and focus group engagement. These conceptions are compared with the scientific and especially pedagogical discourse on the matter as well as Soini and Birkeland's theory of story lines of cultural sustainability and Barth's theory of micro-, median- and macro-levels of culture. The analysis shows that the viewpoint of education brings a new dimension to the discussion on cultural sustainability. It specifically broadens the "culture in" definition from the perspectives of supporting children's and youth's identity process and micro-level encounters. From a theoretical point of view, the study therefore adds depth to the examination of cultural sustainability.
\end{abstract}

Keywords: cultural sustainability, sustainability education, cultural heritage, cultural rights, cultural identity, basic education

\section{Introduction}

In this article conceptions of cultural sustainability (CS) collected through expert queries and focus group engagement are introduced. Second, these conceptions are compared with scientific and especially pedagogical discourse on the matter. The aim of this study is to create an overview of what the Finnish curriculum requirement (NBE, 2014) on the promotion of CS means in basic education. The wide interest towards the learning outcomes of Finnish schools (Niemi, Toom \& Kallioniemi, 2012; Sahlberg, 2015) makes Finland an especially appealing case study in planning and developing culturally sustainable education.

In 2011-2015 the collaborative work on CS by a European research network of approximately one hundred researchers is a prime example of increasing interest in the field. The network, COST Action IS1007 Investigating Cultural Sustainability, carried out transdisciplinary work on the concept and practices of CS. As one result of this collaboration, a three-role approach to defining CS was developed: culture as, in and for sustainable development. The "culture as sustainable development" approach defines culture as the basis or core of sustainability, an approach which generates sustainability. Culture is utilized in finding a new understanding of the human place in the world and 
highlighting one's human role as a potential initiator of change (Dessein, Soini, Fairclough, Horlings, 2015). Based on the previous analysis of the author, change towards a culturally sustainable way of living is achieved through familiar educational themes with various titles such, as environmental and consumer education (see Laine, 2013a). The "culture for sustainable development" approach sees culture as the "glue" which combines ecological, social and economic pillars. The downside is that this definition has not been widely used (Dessein, Soini, Fairclough, Horlings, 2015).

The "culture in sustainable development" approach views culture as having a separate, independent role as part of sustainable development, as a so-called fourth pillar in addition to ecological, economic and social sustainability. In the author's previous analysis, this approach was called cultural specifics (Laine, 2013a). The author sees the "culture in" approach as appealing from the point of view of educational sciences and education as practice, because it highlights such themes as multiculturality, cultural rights, local culture and cultural identity, and other themes that are strongly present in the Finnish national core curriculum. From this point of view, the "culture in" approach expands our way of seeing CS by taking into account the contents of the pillar model approach, which can be utilized in authenticating implications for the individual pupil. In this article, after presenting the data from the "culture in" perspective, I will expand the definition of CS in education by comparing the found conceptions with Soini and Birkeland's theory of story lines of cultural sustainability and Barth's theory of micro-, median- and macro-levels of culture so that a pedagogically relevant definition of cultural sustainability can be achieved.

\section{Research Question, Method and Data}

Because there is no existing definition of education-related contents in the field of CS, the following research question was formulated: What are the experts' conceptions of outlining CS in education? This study is a qualitative study with a multifaceted and detail-oriented approach to the research data. Qualitative research relies on an inductive analysis based on the comprehensive gathering and collection of data in the surrounding environment (Hirsjärvi, Remes \& Sajavaara, 2009). However, including a particular theme or subtheme under the umbrella of culturally sustainable education should not be viewed as the main aspect of this study, but rather the increase in the understanding of the multi-faceted nature of sustainable education. Therefore, after reducing and grouping the research data, the analysis is continued by making deductions based on the subthemes and themes. An additional research question therefore was formulated: How can one supplement experts' conceptions so that a definition of culturally sustainable education would be coherent not only with the data of this study but with the current discussion concerning cultural sustainability and be supplemented with pedagogical aspects from the viewpoint of the Finnish educational system? The latter research question was answered by utilizing Soini and Birkeland's theory of the story lines of cultural sustainability and Barth's theory of the micro-, median- and macro-levels of culture.

The Association of Cultural Heritage Education in Finland was responsible for the collection of the data in 2011 (see Laine, 2013b). The author, employed by the association, collected the research data, which consists of two surveys and memorandums of six focus group meetings. Participants who answered the surveys or attended the group meetings share an interest in CS and work in an expert position and/or in an expert 
leadership position. Their professions include scholars, adjunct professors, teachers and coordinators, and so on. The fact that all the participants are experts is crucial, as the aim of this study is the generation of new information by studying conceptions, not statistical generalizations. Thus, it is pivotal that the participants know the phenomenon under investigation as well as possible. Because no established group of CS experts was available for this study, so-called snowball sampling was used in the data collection phase. Information on possible participants was searched by looking for Finnish studies and articles where cultural sustainability is mentioned. This led to the creation of a mailing list, which was then used to invite people to answer two surveys and take part in focus groups. The experts that were found were also asked to name other experts or researchers or studies, which contributed to finding more experts on cultural sustainability as they were added to the mailing list. In addition to this, the experts on the mailing list were given the opportunity to forward invitations to people they preferred (Tuomi \& Sarajärvi, 2009). None of the participants wished to remain anonymous. The invitations were sent to the cultural sustainability mailing list of the Association of Cultural Heritage Education (466 persons) and were also distributed to other mailing lists by the Finnish Museums Association, the Finnish Association for Environmental Education and the OKKA Foundation (the Foundation's aim is to develop education, and be in responsible for the certification of sustainable development in educational institutions).

The study started by defining CS (electronic survey 1, 23 responses). The respondents were asked to reflect on open questions about cultural sustainability, for example why a particular theme should be considered culturally sustainable. Answers were from one to three pages. Starting the study by defining cultural sustainability was necessary, for no established definition existed in the material collection phase. Outlining education that promotes cultural sustainability therefore also required outlining cultural sustainability. The study then continued with questions on the contents of education (electronic survey 2, 59 responses). This survey was used to outline measures, models, practices and educational needs to achieve cultural sustainability. In addition, values connected to cultural sustainability were outlined. Answers were approximately one page long.

Discussion on the themes of the surveys was expanded in the focus groups (see e.g. Liamputtong, 2011). There were three groups, which each met twice. The invitation was an open one and was sent by e-mail. Groups met in 2011, weeks 43 and 47. Meetings were approximately four hours long. The content of these six meetings were written down as memos, 4-6 pages long, by a secretary and were approved by the participants. The memos are named 1.1-1.3 (week 43) and 2.1-2.3 (week 47). A total of 25 people participated in the groups. The people attending the groups were sent an invitation in advance, which included the agenda and a list of topics to be covered. The first meeting dealt with outlining cultural sustainability in the context of education and related educational values, goals and skills. The second meeting was concerned with culturally sustainable practices, pedagogics and educational needs in the field of education.

The research data was analysed via the method of qualitative data-oriented content analysis to find conceptions which defined CS in education. The units of the analysis were not predefined and theory was generated from within the research material. A typical challenge with data-oriented content analysis that observations are saturated with theory was avoided by proceeding with a systematic and data-oriented approach without comparison to theoretical frameworks. Recurring expressions that describe definitions of education promoting culturally sustainable development were sought after 
in the data. Expressions that were found were grouped into groups of similar expressions, and these groups were then formed into themes (Tuomi \& Sarajärvi, 2009).

Because of fluctuation in the expressions and terms used, the starting point of the analysis was not the maximum recurrence of conceptions in the data. Instead, recurrence of content was looked for, and themes that connected these contents into clusters were created. For example, a subtheme "locality" consists of concepts such as the local environment, local heritage, and local museums. So that the subthemes would describe the participants' connotations as accurate as possible, a description of each subtheme was attached in the results of the study (Figure 1). This was also necessary because the participants did not hold definitions of for example culture, cultural heritage or tradition in common. This study is not therefore bound by any predefined conception of these terms. To take into account the terminological challenges in the analysis, a description of the subthemes' contents has been included with the subthemes. This is to help the reader take note of the complexity of the connotations embedded within a subtheme and also to add reliability. Descriptions of the subthemes paint a more detailed picture of how the subtheme is formulated. The descriptions also help in recognizing the education-related contents of each subtheme.

If an expression only appeared once in the data, this was not considered to be an obstacle for it being incorporated into the analysis. An expression was included in the results if, for example, it had a synonym connection with other expressions or it added information. The expression "international cooperation", for instance, was only mentioned once but because as a term it connects closely to internationality and global education, which were mentioned more often, it was added in the description of the "internationality" theme. This was justified by the fact that "international cooperation" is an explanatory expression used widely in the field of education and is therefore easily approached and understood. The term "sound environments" only mentioned once, brought new information, and was thus included in the description of the subtheme "cultural environment", but not as its own subtheme. The choice to include expressions mentioned only once is based on the tradition of qualitative research and the starting point of the study was to generate new information through experts (Tuomi \& Sarajärvi, 2009).

\section{Concepts Defining Culturally Sustainable Education}

Conceptions defining CS in education were searched for in the surveys and memorandums of focus group meetings. The conceptions were twofold in defining CS. On one hand, the conceptions dealt with the change in school culture towards sustainability ("culture as"), and on the other hand, they were about the intrinsic values of culture ("culture in"). This data analysis focuses on conceptions of CS according to the "culture in" approach, that is to say, on themes which can be seen as representing the view of culture as one of the four pillars of sustainability or, on the other hand, the intrinsic value of culture-related specifics. The deductive analysis presented in the end takes the "culture as" approach into account.

To achieve an overall picture of culturally sustainable education, contents coherent with the "culture in" approach have been looked for in the experts' conceptions in this study. Thus, the earlier study (Laine, 2013a) of the "culture as" approach is supplemented by an attention to the role of culture as a separate, independent part of sustainable development. Grouping and describing the contents offers a more specific view of, for example, 
the content of instruction in culturally sustainable education, and therefore helps the organizers of education such as schools, municipalities and the governmental level take sustainability into account in a more comprehensive way. Eight subthemes, introduced along with their descriptions in Figure 1, were found from the research data: creativity, cultural customs, cultural heritage and awareness of history, cultural landscapes, interaction between generations, internationality, and locality as well as multiculturalism and diversity.

\begin{tabular}{|c|c|c|}
\hline $\begin{array}{c}\text { Example from the original } \\
\text { expression (source in brackets, } \\
\text { translation by author) }\end{array}$ & Subtheme and the description of the subtheme & Themes \\
\hline $\begin{array}{l}\text { "Culturally sustainable } \\
\text { education appreciates } \\
\text { individual creativity, insight } \\
\text { and differences." (Memo 1.3) }\end{array}$ & $\begin{array}{l}\text { CREATIVITY: } \\
\text { - different forms of art, such as architecture, music, } \\
\text { design, handicrafts, literature and language } \\
\text { - creativity in day-to-day life (e.g. dressing) } \\
\text { - memory organizations preserving creative content } \\
\text { such as libraries } \\
\text { - the right to participate in culture and visit culture } \\
\text { organizations }\end{array}$ & \multirow{4}{*}{ 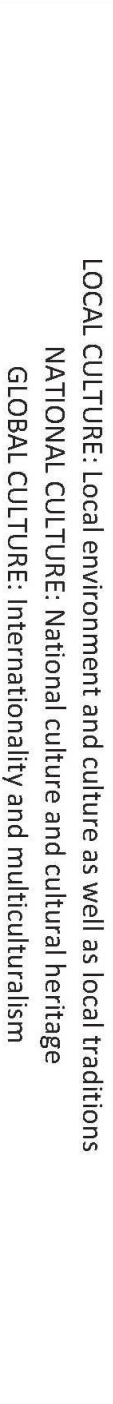 } \\
\hline $\begin{array}{l}\text { "A person acting according to } \\
\text { cultural sustainability masters } \\
\text { cultural customs and knows } \\
\text { how to get along with people } \\
\text { who represent different } \\
\text { cultures." (Memo 1.3) }\end{array}$ & $\begin{array}{l}\text { CULTURAL CUSTOMS: } \\
\text { - knowledge of customs } \\
\text { - school festivities } \\
\text { - celebrations (e.g. Kalevala Day) }\end{array}$ & \\
\hline $\begin{array}{l}\text { "Appreciation of ones own } \\
\text { culture and heritage, } \\
\text { cherishing and maintaining } \\
\text { them. This doesn't need to } \\
\text { mean becoming stuck in the } \\
\text { past, but learning from it: } \\
\text { adapting one's heritage to } \\
\text { modern life." (Survey I) }\end{array}$ & $\begin{array}{l}\text { CULTURAL HERITAGE AND AWARENESS OF HISTORY } \\
\text { - preservation and transmission of cultural heritage } \\
\text { and traditions } \\
\text { - sense of time perspective and awareness of history } \\
\text { - adapting and transforming one's cultural heritage } \\
\text { (e.g. food and celebrations culture, built heritage, } \\
\text { profession cultures, spoken tradition, religion } \\
\text { heritage) } \\
\text { - storage of heritage, heritage organizations such as } \\
\text { museums and art institutions } \\
\text { - plant heritage }\end{array}$ & \\
\hline $\begin{array}{l}\text { "Cultural landscapes and } \\
\text { natural heritage are very } \\
\text { suitable viewpoints for pre and } \\
\text { basic education, also for day- } \\
\text { to-day sustainable functions in } \\
\text { early childhood education as } \\
\text { part of environmental } \\
\text { education." (Survey II) }\end{array}$ & $\begin{array}{l}\text { CULTURAL LANDSCAPES: } \\
\text { - architecture } \\
\text { - contextual architecture and development works } \\
\text { - developing infrastructure anthropocentrically } \\
\text { - history appearing in the environment } \\
\text { - natural heritage } \\
\text { - landscapes } \\
\text { - ecosystem services } \\
\text { - the sound environment } \\
\text { - plants and gardens } \\
\text { - living off nature: picking berries and mushrooms, } \\
\text { hunting, working with natural materials }\end{array}$ & \\
\hline
\end{tabular}

Figure 1. Examples of Original Expressions, Subthemes With their Descriptions and Themes Derived From the Data 


\begin{tabular}{|c|c|c|}
\hline $\begin{array}{l}\text { Example from the original } \\
\text { expression (source in brackets, } \\
\text { translation by author) }\end{array}$ & Subtheme and the description of the subtheme & Themes \\
\hline $\begin{array}{l}\text { "Culturally sustainable } \\
\text { development takes different } \\
\text { generations into account." } \\
\text { (Memo 1.3) }\end{array}$ & $\begin{array}{l}\text { INTERACTION BETWEEN GENERATIONS: } \\
\text { - learning from and appreciating one's family } \\
\text { - transmission of knowledge and skills } \\
\text { - dealing with issues from the past (difficult } \\
\text { heritage) } \\
\text { - bringing together different generations and times }\end{array}$ & \multirow{4}{*}{ 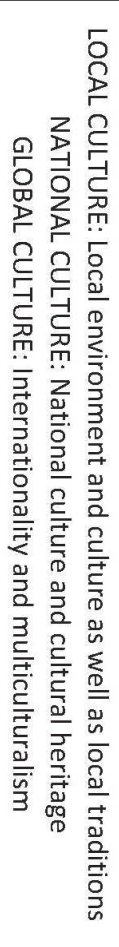 } \\
\hline $\begin{array}{l}\text { "From the standpoint of } \\
\text { sustainable development, one } \\
\text { should see examples from } \\
\text { different cultures alongside } \\
\text { with ones identity and } \\
\text { surroundings so that } \\
\text { development could be globally } \\
\text { sustainable." (Memo 1.2) }\end{array}$ & $\begin{array}{l}\text { INTERNATIONALITY: } \\
\text { - global education } \\
\text { - international collaboration } \\
\text { - the world as a learning environment }\end{array}$ & \\
\hline $\begin{array}{l}\text { "Co-operation with the } \\
\text { surrounding community and } \\
\text { local actors provides a working } \\
\text { ground for cultural education." } \\
\text { (Survey II) }\end{array}$ & $\begin{array}{l}\text { LOCALITY: } \\
\text { - working with local culture (e.g. local museums) } \\
\text { - close by nature } \\
\text { - local heritage }\end{array}$ & \\
\hline $\begin{array}{l}\text { "Multiculturalism and growing } \\
\text { to be part of it is culturally } \\
\text { sustainable." (Survey II) }\end{array}$ & $\begin{array}{l}\text { MULTICULTURALISM AND DIVERISTY } \\
\text { - cultures, traditions, different cultural heritages, } \\
\text { religions } \\
\text { - consideration of pupils with immigrant } \\
\text { backgrounds } \\
\text { - dialogue between cultures }\end{array}$ & \\
\hline
\end{tabular}

Sequel to Figure 1. Examples of Original Expressions, Subthemes With their Descriptions and Themes Derived From the Data

The example of an original expression found under the subtheme "cultural customs" (see Figure 1) describes the nature of the research data and the steps of the analysis well. The expression describes the contents of two subthemes ("multiculturality" and "cultural customs") and shows the overlapping nature of the themes. Cultural customs is part of multiculturality but cultural customs are not necessarily multicultural. So, the data reflects respecting and transmitting local and national culture and at the same time the data reflects the multiculturality approach. No preference for either of the two approaches is, however, present in the research data. Neither was there any explicit expression of national or local culture not being viewed as diverse in itself - a need, for example, to define Finnish cultural heritage as consisting of particular, invariable content was not found in the data. The lack of expressions, however, does not exclude the existence of such thinking as an implicit supposition.

In addition to the subthemes, three main themes can be distinguished from the research data: local culture, national culture, and global culture. As the previous example of the subtheme "cultural customs" indicates, the main themes have not been generated based on the contents of one or a few subthemes, but instead reflect the contents of the whole data. It should be noted, that the themes are not used to outline culture as either local, national or global. Culture crosses boundaries and is ever-changing. The themes 
are used to explicate the educational approach evident in the research data: education should take into account the expression of culture on a local, national and global level. In addition to this, it is important to acknowledge the previous or still ongoing critical discourse on many of the terms being used, and that the participants are not committed to using just one definition of any of the terms. The term "multiculturality", for instance, has been criticized for not reflecting the diversity on the micro-level and that using the term even falsely creates many cultures (e.g. Saukkonen, 2013). I now continue the analysis and interpretation of the results by using Soini and Birkeland's theory of story lines of cultural sustainability and Barth's theory of micro-, median- and macro-levels of culture.

\section{Culturally Sustainable Education and the Scientific/Political Discourse on Cultural Sustainability}

In this section, the way in which descriptions of culturally sustainable education relate to the scientific discourse on CS is explored. This is done by using Soini and Birkeland's theory of story lines of cultural sustainability. It is important to see whether the results of this study resonate with the broader scientific discourse - to see whether this study adds to the scientific discourse and to see what kind of themes that are missing from the research data of this study can be found in the scientific discourse.

Soini and Birkeland have organized the scientific discourse on CS around seven story lines that are partly interlinked and overlapping but differ in terms of how the contextualized aspects are grouped. From these story lines they created a summary of the political contexts of CS (Soini \& Birkeland, 2014). It should be noted, however, that the results of Soini and Birkeland's discourse analysis are tied to political discourse and its established concepts and not to scientific theories, so the definition of CS and terms connected to it are disconnected from their original context in the articles they examined, nor are they analysed on a meta-level. This does not diminish the usability of the results of Soini and Birkeland's analysis, although it is important to continue the analysis of their data by comparing the results with scientific theories so that the definition of CS can be examined on levels other than normative discussion and the terms used in it. Moreover, discussion on education and its goals should also take into account the underlying pedagogical decisions. These themes will be discussed later in this article.

Cultural heritage and the use of heritage and culture are common themes in the scholarly discourse on CS. Soini and Birkeland's analysis of the cultural heritage story line describes cultural heritage (tangible and intangible) as a stock of cultural capital that has been inherited from previous generations and can be transmitted to future generations. The use of cultural heritage and cultural services form the base of the cultural vitality story line. This second story line is concerned with how cultural services, events and heritage meet the changing needs of their users and how cultural heritage is made accessible in a sustainable way. This story line sees cultural change driven by globalization and technology as mainly positive, but at the same time it raises the question how the change can take place without damaging cultural continuity or identity or cultural capital (Soini \& Birkeland, 2014). These two story lines represent the conservative context of the political aspects of CS. The conservative political context is also present in the research data of this study: cultural heritage and cultural vitality are both seen as part of culturally sustainable education (see Figure 1 ). The conservative political context 
also represents the pillar model of sustainability, the "culture in" approach to sustainability.

The third story line, economic viability, adopts heritage as a resource for economic vitality and emphasizes a dynamic approach to culture and the reproduction of culture. This story line represents the neoliberal context of the political aspects of CS (Soini \& Birkeland, 2014). Although the data of this study does not explicitly mention culture from the viewpoint of economic viability, the themes of the conservation of cultural vitality by applying traditions to modern day, maintaining different skill sets, development, and media visibility are present. In addition, the significance of architecture, land use and construction are well presented. These mentions can be seen as having links with the story line of economic viability, although economic viability in itself does not come up as a theme in defining culturally sustainable education.

The cultural diversity story line refers to the recognition of the diversity of values, perceptions, attitudes and material cultural manifestations. The story line, however, presents an instrumental conception of culture. Cultural acceptance is seen as important in promoting the implementation of development schemes designed to reach environmental goals or to improve the quality of life of local people. The fifth story line, locality, is linked to cultural diversity as it emphasizes the perceptions and cultural rights of ethnic minorities, indigenous people and other marginalized people whose capabilities to participate in or defend their rights are threatened. This story line prefers locally based development to global development. New livelihoods and activities are often seen as a threat. Involvement of locals in planning and decision-making, as well as a deeper understanding of local cultural practices, is emphasized. These two story lines represent the communitarian context of the political aspects of CS, but are partly contradictory in their approach to globalization. The cultural diversity story line represents a globalization approach whereas the locality story line is anti-globalist. All in all, with the exception of the economic viability story line, the majority of the story lines see CS as threatened by globalization (Soini \& Birkeland, 2014). This rejecting attitude towards globalization is partly present in the research data of this study, but does not play a central role. The data of this research seems to be more in line with the Finnish National Core Curriculum, which instructs students to operate in a global world and encourages international interaction as well as consideration of the local environment (NBE, 2014). The themes these two story lines represent are present in the research data of this study but contrast with the viewpoint of Soini and Birkeland's study on scientific discourse, where culture was seen as having an instrumental value. Whereas these story lines view culture as a means to an end (sustainability e.g. culture having an instrumental value as an instrument to achieving sustainable future), the research data of this study consists of two separate perspectives with respect to the themes of these two story lines: the first representing the instrumental "culture as" approach as introduced in the author's previous research and the second representing the "culture in" approach as introduced in the analysis of this article (culture having an independent role in sustainability).

The two remaining story lines, eco-cultural resilience and eco-cultural civilization, represent the environmental context of the political aspects of CS (Soini \& Birkeland, 2014). Eco-cultural resilience seeks a balance between humans and nature. Nature conservation therefore cannot be carried out without taking local livelihood development into consideration. Eco-cultural civilization on the other hand refers to an ecological turn in the values and behaviour of people (Soini \& Birkeland, 2014). These narratives, along 
with the three previously mentioned narratives, are linked to the instrumental values of culture and cultural change as presented in the "culture as" perspective of CS. Because the "culture as" approach is present in the data of this research (for the need for cultural change towards sustainability, see also Laine, 2013a), it is therefore inevitable to combine both perspectives, the "culture as" approach and the "culture in" approach, in the final description of culturally sustainable education.

To summarize: the data of this study matches Soini and Birkeland's conservative, communitarian and environmental aspects on CS. It remains open whether the definition of education which promotes CS should in this regard be broadened with a stronger neoliberal approach. In addition, the data of this study differs from Soini and Birkeland's analysis from the viewpoint of cultural diversity and locality: the rejection of globalization and culture's instrumental value do not play a similar prominent role. There is also a call for culture's intrinsic value emerging from the data of this research as presented in the previous chapter when comparing it to Soini and Birkeland's analysis. Next the possibility of supplementing Soini and Birkeland's analysis from the perspective of the educational sciences will be discussed so that a definition of culturally sustainable education would be coherent with not only the data of this study and the current discussion concerning cultural sustainability (e.g. Soini and Birkeland's analysis of the scientific discourse) but supplemented with pedagogical aspects from the viewpoint of the Finnish educational system.

\section{Pedagogical Perspectives on Culturally Sustainable Education}

It is important to broaden the examination of CS education beyond normative conceptions and the political context and examine its definition in connection with pedagogical discourses, so that the definition of culturally sustainable education would be coherent with the current discussion on education practice and policies. Therefore in this section the definition of culturally sustainable education in relation to pedagogics will be examined, utilizing anthropologist Fredrik Barth's (1928-2016) theory of the micro-, median- and macro-levels of culture. The way in which Finnish educational politics, the national core curriculum of basic education and the organization of education and educational practices take into account CS and thus participate in its definition will also be discussed. Through these approaches, a pedagogical level of CS is presented and a definition of culturally sustainable education is reached.

Even though Barth's model of analysis, which is used in understanding the relations between power, organizational activity and everyday human life, has been created to study ethnicity, the model has been broadly applied in the study of culture (e.g. Siivonen, 2008). In this study, Barth's theory is used in formulating the visibility and operations of CS on different levels. The micro-level represents the level of individual people, the median-level represents the level of local organization and institutions, and the macrolevel represents the level of states, international organizations and institutions. Everyday life happens on the micro-level, in interaction with one's own environment and the level of symbols, with variation accounted for. Culture on the micro-level is therefore not unified. On the median-level, simplified images of culture are generated. This enables simplifications to be used in the promotion of culture. On the macro-level the conditions for operation, and the possibility of micro- and median level operations, are created. On the macro-level power over the micro- and median-levels are exercised. The median- 
level also includes the exercise of power in relation to the micro-level (Barth, 1994; Siivonen, 2008). The exercise of power on the macro- and median-levels does not, however, imply that the relations between different levels are only one-way. In education the requirements of the micro-level guide the decisions on the macro-level and the operations on the median-level. The curriculum, for example, is modified and legislation reformed on the basis of encounters on the micro-level and the requirements arising from them. Also, the organizations and institutions operating on the median-level aim at meeting the requirements of the micro-level. The manifestation of the different levels in culturally sustainable education is described in Figure 1.

Barth's view of the encounters on the micro-level is especially interesting from the viewpoint of educational sciences, for it adds a level where CS is alive and develops in everyday situations and encounters into a discussion of CS alongside of the normative definition. On the level of schools this means turning attention to pupil-pupil, pupilteacher and teacher-teacher encounters. From Barth's model it can be noticed that CS is defined on the macro- and median-levels, but definitions arising in the micro-level contacts have not yet been studied in education. Topics broadly discussed in educational sciences, such as identity processes (e.g. Benjamin, 2014), pupil encounters (e.g. Talvio, 2014) and other pedagogic decisions, such as the critical pedagogy view of the pupil as an active, world-reforming actor (e.g. Apple, Au \& Gandin, 2009) can, on the other hand, be seen as studies of micro-level encounters.

The levels of manifestation of CS on the macro- and median-level, visible in Figure 1, include the perspectives of educational politics, educational administration and organizing education. These viewpoints are utilized in showing what kinds of CS themes have been given specific attention in developing and guiding education. On the macrolevel, sustainable development education is mentioned in several normative documents guiding education. The Finnish Government along with the Ministry of Education and Culture are responsible for the planning and execution of educational politics. The Finnish National Board of Education is a department for developing education, which, among other things, decides on the curriculum (NBE).

The memorandum on the reform of Finnish basic education by the Ministry of Education and Culture in Finland states that the future skill requirements are, among other things, understanding the challenges of sustainable development and taking care of the future. From the perspective of the "culture in" approach, the following skill requirements are mentioned: understanding different customs, languages and cultures in a globalizing world, readiness regarding creativity, skills related to self-expression, hand and body skills and being conscious of one's own identity. The Ministry memorandum pays particular attention to multiculturality - it notes that the increase in the diversity of languages, cultures and religions requires that schoolwork should be supportive of both the construction of a pupil's own cultural identity and his/her participation in Finnish society and a globalizing world. Several statements and expert resolutions in the Ministry memorandum also highlight the increasing importance of cultural and life stance education in the future (MEC, 2010). A presentation on the goals and distribution of lesson hours in basic education, which followed the 2012 memorandum, mention the promotion of sustainable development as a goal of basic education. Socio-cultural sustainability is mentioned, although the confirmed national core curriculum (2014) mentions CS in its own right (MEC, 2012). 
In the national core curriculum of basic education 2014, a sustainable way of living is viewed as a necessity. A sustainable future and way of living is shown as a crosssectional theme in the document. CS is specified as one of the dimensions of a sustainable way of living, and is mentioned in the value base of basic education and the transversal competence goals (NBE, 2014). The "culture in sustainability" approach is present in, for example, the cultural objective of basic education, which defines the objective of basic education as promoting diverse cultural competence and appreciation of one's cultural heritage, and as supporting pupils in the construction of their own cultural identity and cultural capital. The transversal competence goals mention the construction of one's cultural identity, too, and cultural competence is selected as one of the seven competence goals. School culture is described as utilizing and appreciating the nation's cultural heritage and national languages, and one's own and the surrounding cultural, linguistic, religious and life stance diversity. In the discussion on cultural diversity, the right to one's own language and culture is noted as being a fundamental right (NBE, 2014). The CS and the "culture in sustainability" perspective are also visible in subjects and the general goals of school grades (for a more specific analysis, see Laine, 2016).

In light of what has been said above, the themes of CS from the viewpoint of educational politics are connected to the learning goals and rights of the individual arising from the societal situation (e.g. globalization, multiculturality) and values (sustainable ways of living, appreciation of cultural diversity and traditions), and to the societal level as enabling the actualization of rights and the achievement of learning goals. The contents do not contradict the previously introduced results or the scientific-political discourse, but it is noteworthy that the themes of cultural identity, cultural competence and cultural rights particularly stand out. Educational politics is therefore utilized in bringing the individual's learning requirements, in relation to both personal and societal requirements, into the discussion on CS, so that an attempt is made at meeting the requirements of the micro-level encounters.

Organizing education to promote a sustainable way of living has in Finland been supported by both organizations and the Government (Kestävän kehityksen toimikunnan koulutusjaosto, 2006; ME 2006; see also: Pathan et al., 2012). On the median-level, in 2007 the National Board of Education published a manual on promoting sustainable development in educational institutions. In the manual, the "culture in" approach is visible in taking into account cultural identity, cultural heritage, multiculturality and local culture (Loukola, 2007). Organizations have also provided concrete tools for promoting culturally sustainable development in education. The OKKA Foundation, which aims at developing education, is in charge of the certification of sustainable development in educational institutions and one of its themes is CS (see www.koulujaymparisto.fi). The Association of Cultural Heritage Education in Finland has published a website, www.kulttuurinvuosikello.fi, promoting culturally sustainable education. The Helsinki Metropolitan Area Reuse Centre has, as part of the 4V project, produced sustainability guides including CS to day care centres, schools and playgrounds (see www.4v.fi). On the median-level, activity that furthers culturally sustainable education includes the culture education provided by municipalities and schools and specifically all activity that is based on the cultural education plans and reaches all pupils equally (see www.kulttuurikasvatussuunnitelma.fi). 


\begin{tabular}{|c|c|c|}
\hline MACRO-LEVEL & MEDIAN-LEVEL & MICRO-LEVEL \\
\hline $\begin{array}{l}\text { - legislation concerning } \\
\text { education } \\
\text { - education policy } \\
\text { - educational administration } \\
\text { and the national core } \\
\text { curriculum }\end{array}$ & $\begin{array}{l}\text { - NGOs and local agents } \\
\text { - municipal and school level } \\
\text { curriculums } \\
\text { - school administration }\end{array}$ & $\begin{array}{l}\text { - day-to-day encounters in } \\
\text { school } \\
\text { - recognition and } \\
\text { actualization of cultural } \\
\text { rights } \\
\text { - well-balanced } \\
\text { development of } \\
\text { (cultural)identity } \\
\text { - cultural know-how and } \\
\text { mastery and support of } \\
\text { cultural skills }\end{array}$ \\
\hline $\begin{array}{l}\rightarrow \text { power is used with the } \\
\text { help of normative } \\
\text { descriptions } \\
\rightarrow \text { cultural activity, } \\
\text { homogeneity and stability as } \\
\text { an instrumental goal when } \\
\text { pursuing societal peace, } \\
\text { wellbeing and economic } \\
\text { benefits }\end{array}$ & $\begin{array}{l}\rightarrow \text { power is used when } \\
\text { controlling micro-level } \\
\text { functions } \\
\rightarrow \text { sustaining cultural activity, } \\
\text { homogeneity and stability as } \\
\text { a goal by deploying macro- } \\
\text { level goals and sorting out } \\
\text { and answering to micro-level } \\
\text { needs }\end{array}$ & $\begin{array}{l}\rightarrow \text { these aspects resonate } \\
\text { with the definitions of the } \\
\text { macro and median-levels, but } \\
\text { adjusted in accordance with } \\
\text { interactively in day-to-day life } \\
\rightarrow \text { active structuring of the } \\
\text { world and operating in it with } \\
\text { relation to others as a goal }\end{array}$ \\
\hline \multicolumn{3}{|c|}{$\begin{array}{l}\rightarrow \text { The effect of the macro-level via the median-level to the micro-level: } \\
\text { homogeneity, stability, activity }\end{array}$} \\
\hline \multicolumn{3}{|c|}{$\begin{array}{c}\text { The effect of the micro-level via the median-level to the macro-level: } \\
\text { heterogeneity, variation, activity } \leftarrow\end{array}$} \\
\hline
\end{tabular}

Figure 2. The Appearance of Cultural Sustainability in Education According to Barth's Levels of Culture (Barth, 1994; Siivonen, 2008)

\section{The Definition of Culturally Sustainable Education}

In order that, for example, programmes, certificates, websites and publications aimed at promoting sustainability education - and used by both the teachers and the pupils - cover sustainability from a broad perspective (including cultural sustainability) a definition of culturally sustainable education must be generated. To meet the curriculum requirements for culturally sustainable education, education should take into account, for instance, the diversification of society and the pupil's individual cultural identity. Education is, however, linked to the information at hand and to existing practices and services. In the research data of this study, the strengthening of one's own identity and one's own roots was considered a central development target in educational practices, along with appreciating, treasuring, upholding and maintaining one's own culture and traditions, while applying them to the present time (e.g. memorandum 2.3). On a societal level, the UN Declaration of Human Rights and the right to one's own language and culture were mentioned. The societal changes and the significance of an individual's cultural identity highlighted by educational politics and the educational administration are in line with expressions in the research data concerning the support of the individual's identity process and societal diversification, which are clearly shown in the subthemes as well. The analysis of the definition of culturally sustainable development therefore 
expands the significance of the "culture in" aspect, especially from the perspective of the individual's development and micro-level encounters. Micro-level encounters raise such questions "Do I enable cultural changes?" or "Whose creativity is accepted and valued?" and "Do I accept critical interpretations of culture?" (see more specifically Laine, 2013a).

By combining the environmental approach that takes into consideration the instrumental value of culture (cultural change) and the CS approach that is in accordance with the pillar model that recognizes the intrinsic value of culture, a definition of culturally sustainable education is arrived at. This definition also resonates with the scientific discourse on CS and with earlier definitions of education that promote CS (Laine, 2013a). To take into consideration pedagogical viewpoints, a definition of culturally sustainable education must also acknowledge the significance of culture in the learner's identity process. In supporting the identity process, cultural rights and their identification and acknowledgement hold a central role. It is important to note that neither the research data nor the national core curriculum mention cultural identity or cultural heritage as being tied to one specific nationality or, for instance, ethnic background, but is seen as a right of all people.

Taking into consideration the results of the analysis of the research data presented, the comparison of results with the scientific and political discourse presented and the pedagogical factors, the results of the analysis can be summarized thus:

Culturally sustainable education

- is made possible and developed through micro-, median- and macro-level contacts

- takes into account culture on the local, national and global levels

- includes creativity, cultural customs, cultural heritage and an awareness of history, cultural landscapes, interaction between generations, internationality, locality as well as multiculturalism and diversity in education

- supports the identity process of the pupil

- protects and enables the realization of cultural rights

- utilizes the instrumental value of culture and recognizes the value of culture in the cultural change toward sustainability.

This study shows that expert conceptions of culturally sustainable education do not conflict with scientific or pedagogical discourse. This in itself shows the generalizability of the results of this study. It is also interesting to note that the experts' conceptions did not include the neoliberal dimension, as in the notion that culture is an economic asset (for the commercial use of culture and benefits from tourism and travel, see Siivonen, 2009, and for sustainable design, see Ruokonen, Sepp, Moilanen, Autio \& Ruismäki, 2014). It would be possible to apply the commercial aspects of culture in schools with entrepreneurship education and practical subjects. Additionally, there was no specific interest present in the research data to categorize certain contents as preserving and transmitting Finnish culture. This resonates with the idea that is present in the research data, namely that culture is multi-faceted and changing but it is also a local phenomenon. Even though the results do not conflict with scientific and pedagogic discourse, they do show that the educational viewpoint introduces a new dimension into the discussion on CS. It specifically broadens the "culture in" definition from the perspectives of supporting the pupil's identity processes and micro-level encounters. From a theoretical point of view, the study therefore adds depth to the examination of CS. At the same time, the 
results of this study should be exposed to critical review of what the terms used in defining culturally sustainable education, as in multiculturality and communality, mean from the perspectives of the pupil's identity process, welfare and positive societal development (e.g. for indigenous perspectives, see Chandra, 2014).

\section{Conclusions}

The objective of the study, to find a definition for culturally sustainable education, was answered by creating a synthesis of experts' conceptions, earlier research, scientific discourse and pedagogic viewpoints. Through this study, the expectations for education from the viewpoint of CS can be defined more explicitly and in an approachable way. Moreover, Soini and Birkeland's theory of story lines regarding CS is supplemented to take into account micro-level encounters and pedagogics and on the other hand Soini and Birkeland's theory shows that the data from this study could be supplemented with an approach that also considers the commercial possibilities of culture.

Pursuing a sustainable way of living is about broadening the whole educational system's way of thinking, about a new school culture. Without acknowledging the cultural perspective, the pursuit of sustainability fails. Culturally sustainable education considers culture in a broad and diverse way. Thus, an educational institution cannot achieve a good level of CS by taking into consideration only one aspect of CS and disregarding others. Nor can a school achieve a good level of sustainability by only acknowledging one aspect of sustainability. Defining cultural sustainability is pivotal so that education can reach a future-orientated vision of CS that supports the wellbeing of the pupil and society.

\section{References}

Apple, M. W. \& Au, W. \& Gandin, L. A. (2009). The Routledge international handbook of critical education. New York: Routledge.

Barth, F. (1994). Enduring and emerging issues in the analysis of ethnicity. The anthropology of ethnicity - Beyond ethnic groups and boundaries. Amsterdam: Het Spinhuis.

Benjamin, S. (2014). Kulttuuri-identiteetti - merkitys kasvulle ja kehitykselle [Cultural identity - significance for development and growth]. Kulttuuri-identiteetti \& kasvatus - Kulttuuriperintökasvatus kotoutumisen tukena [Cultural identity \& education - Supporting integration with heritage education]. Helsinki: Suomen Kulttuuriperintökasvatuksen seura. 58-108.

Chandra, D. V. (2014). Re-examining the importance of indigenous perspectives in the western environmental education for sustainability: "From tribal to mainstream education". Journal of Teacher Education for Sustainability, 16(1), 117-127. DOI: $10.2478 /$ jtes-2014-0007

Costandius E. (2010). Using art as a medium to enhance social responsibility and citizenship. Discourse and Communication for Sustainable Education, 2(1), 74-81. DOI: $10.2478 /$ dcse-2013-0016

Dessein J., Soini, K., Fairclough, G. and Horlings, L. (eds) (2015). Culture in, for and as sustainable development. Conclusions from the COST action IS1007 investigating cultural sustainability. Finland: University of Jyväskyla. 
Franzenburg, G. (2016). Sustainability by education: How Latvian heritage was kept alive in German exile. Discourse and Communication for Sustainable Education. 6(1), 100-112. DOI: 10.1515/dcse-2016-0007

Hirsjärvi, S. \& Remes, P. \& Sajavaara, P. (2009). Tutki ja kirjoita (Study and write). 15. uudistettu painos. Helsinki: Kustannusosakeyhtiö Tammi.

Kestävän kehityksen toimikunnan koulutusjaosto. Kestävää kehitystä edistävän kasvatuksen ja koulutuksen strategia ja sen toimeenpanosuunnitelma 2006-2014 [Strategy and implementation for sustainability education 2006-2014]. Helsinki: National Board of Education.

Laine, M. (2013a). Kulttuurin saamat merkitykset kestävää kehitystä edistävän kasvatuksen näkökulmasta [Definitions of culture in sustainability education]. Kestävä kasvatus - kulttuuria etsimässä [Sustainable education - looking for culture]. Helsinki: Suomen Kulttuuriperintökasvatuksen seura, 26-38.

Laine, M. (ed.) (2013b). Kestävä kasvatus - kulttuuria etsimässä [Sustainable educationlooking for culture]. Helsinki: Suomen Kulttuuriperintökasvatuksen seura.

Laine, M. (2016). Kotiseututoimijat koulun tukena [Local heritage actors supporting schools]. Kotiseutu 2016 [Local Heritage 2016]. Helsinki: Suomen Kotiseutuliitto.

Liamputtong, P. (2011). Focus group methodology: principles and practices. Los Angeles: Sage.

Loukola, M. (2007). Käsikirja kouluille ja oppilaitoksille: Kestävän elämäntavan oppiminen - Kestävä kehitys opetukseen, arkikäytäntöihin ja toimintakulttuuriin [Handbook for schools: learning sustainability - Sustainability for teaching, day-to-day activities and practices]. Helsinki: National Board of Education.

ME (Ministry of Education / Opetusministeriö) (2006). Kestävän kehityksen edistäminen koulutuksessa-Baltic 21E-ohjelman toimeenpano sekä kansallinen strategia YK:n kestävää kehitystä edistävän koulutuksen vuosikymmentä (2005-2014) varten. Opetusministeriön työryhmämuistioita ja selvityksiä 2006:6. [Implementation and strategy for Baltic 21E agenda and the strategy for the UN decade of education for sustainability 2005-2014]. Helsinki: Opetusministeriö.

MEC (Ministry of Education and Culture / Opetus- ja kulttuuriministeriö) (2010). Perusopetus 2020 - yleiset valtakunnalliset tavoitteet ja tuntijako. Opetus- ja kulttuuriministeriön työryhmämuistioita ja selvityksiä 2010:1. [Basic education 2020 national objectives and distribution of lesson hours]. Helsinki: Opetus- ja kulttuuriministeriö, koulutus- ja tiedepolitiikan osasto.

MEC (Ministry of Education and Culture / Opetus- ja kulttuuriministeriö) (2012). Tulevaisuuden perusopetus ja tuntijako. Opetus- ja kulttuuriministeriön työryhmämuistioita ja selvityksiä 2012:6. [Future of basic education and distribution of lesion hours]. Helsinki: Opetus- ja kulttuuriministeriö, koulutus- ja tiedepolitiikan osasto.

NBE (National Board of Education) (2014). Valtakunnalliset perusopetuksen opetussuunnitelman perusteet [The national core curriculum for basic education]. Helsinki: Opetushallitus.

NBE (National Board of Education). Retrieved February 27, 2016, from: http://www. oph.fi/opetushallitus

Niemi, H., Toom, A. \& Kallioniemi, A. (eds.), (2012). Miracle of education - The principles and practices of teaching and learning in Finnish schools. Rotterdam: Sense Publishers. 
Pathan, A. \& Bröckl, M. \& Oja, L. \& Ahvenharju, S. \& Raivio, T. (2013). Kansallisten kestävää kehitystä edistävien kasvatuksen ja koulutuksen strategioiden toimeenpanon arviointi. Final report 11.10.2012. [Strategy evaluation of sustainability education and implementation]. Helsinki: Gaia Consulting Oy.

Ruokonen I, Sepp, A., Moilanen, V., Autio, O. \& Ruismäki, H. (2014). The Finnish five-string kantele: sustainably designed for musical joy. Journal of Teacher Education for Sustainability, 16(1), 76-88. DOI: 10.2478/jtes-2014-0004

Sahlberg, P. (2015). Finnish lessons 2.0: What can the world learn from educational change in Finland? New York: Teachers College Press.

Saukkonen, P. (2013). Erilaisuuksien Suomi - Vähemmistö- ja kotoittamispolitiikan vaibtoehdot. [Finland of differences - Alternatives for minority and integration politics]. Helsinki: Gaudeamus.

Siivonen K. (2008). Saaristoidentiteetit merkkien virtoina - Varsinaissuomalainen arki ja aluekehitystyö globalisaation murroksessa. [Archipelago identities as streams of signs - Everyday life and local development in Southwest Finland as a part of global transition]. Helsinki: Suomen muinaismuistoyhdistys.

Siivonen K. (2009). Osallistava kulttuurituotanto - Pohdintaa kulttuurisesta kestävyydestä [Participating in cultural management - thoughts on cultural sustainability]. Kulttuurituotanto - Kehykset, käytännöt ja prosessit [Cultural management outlines, practices and processes]. Helsinki: Suomalaisen Kirjallisuuden Seura.

Silina-Jasjukevica G. I. \& Briska (2016). In-depth cultural studies in multicultural group. Discourse and Communication for Sustainable Education, 6(1), 139-149. DOI: $10.1515 /$ dcse-2016-0010

Soini, K. \& Birkeland, I. (2014). Exploring the scientific discourse of cultural sustainability. Geoforum, 51, 213-223.

Talvio, M. (2014). How do teachers benefit from training on social interaction skills? Developing and utilising an instrument for the evaluation of teachers' social and emotional learning. Helsinki: University of Helsinki.

Tuomi, J. \& Sarajärvi, A. (2009). Laadullinen tutkimus ja sisällönanalyysi. 6th renewed edition. [Qualitative research and content analysis]. Helsinki: Kustannusosakeyhtiö Tammi.

Correspondence concerning this paper should be addressed to Marja Laine, a PhD student, Department of Teacher Education, Faculty of Behavioural Sciences, University of Helsinki, P.O. Box 9, FIN-00014 University of Helsinki, Finland. E-mail: marja.h.laine@gmail.com 